\title{
Considerations on the biology of Plesionika edwardsi (Brandt, 1851) (Decapoda, Caridea, Pandalidae) from experimental trap catches in the Spanish western Mediterranean Sea*
}

\author{
M. GARCÍA-RODRIGUEZ1 ${ }^{1}$ A. ESTEBAN² and J.L. PEREZ GIL ${ }^{2}$ \\ ${ }^{1}$ Instituto Español de Oceanografía, Servicios Centrales, Avda. del Brasil 31, 28020 Madrid, Spain. \\ E-mail: mariano.garcia@md.ieo.es \\ ${ }^{2}$ Instituto Español de Oceanografía, Centro Oceanográfico de Murcia, C/ Varadero 1, \\ 30740 San Pedro del Pinatar, Murcia, Spain.
}

\begin{abstract}
SUMMARY: In this study, the results obtained from three experimental trap shrimp (Plesionika edwardsi) fishing cruises in three different seasons are presented. They were carried out during a total of 50 days, of which 43 days were of effective fishing, covering the whole Spanish Mediterranean coast including the island of Alborán. On the whole, the fishing depth varied between 220 and $384 \mathrm{~m}$, with a mean depth of $318 \mathrm{~m}$. The target species appeared in $81 \%$ of the total samples carried out, with a mean yield (срие) of $108.6 \mathrm{~g} / \mathrm{trap} / \mathrm{day}$. The largest yields (срие) of this species were from the Balearic islands, followed by Levant region, whereas the Alborán sea gave the lowest yields. The largest mean length was observed on the Levant zone, but on the contrary the smallest mean lengths were found towards the south, more specifically at Alborán island. Significant differences were found in both the relative and absolute growth, between males and females, with equilibrium in the ratio of the sexes (0.49). A total of 15 crustacean and 12 fish species were identified as accompanying fauna, with Conger conger, Plesionika narval and Scyliorhinus canicula being the most important, based on their mean сриe, although differences in the appearance and yields of the species were found in the different zones and depths. However, the mean yields of these species were very low, due to the high selectivity of the fishing gear used. The appearance of Heterocarpus ensifer, deserves a special mention, since it is the second documented record of the species in the Mediterranean.
\end{abstract}

Key words: trap-fishery, Plesionika edwardsi, Pandalidae, biology, western Mediterranean Sea.

\section{INTRODUCTION}

In the Spanish Mediterranean, the use of traps in artisanal fishing is an activity that has been falling into disuse as a means of productive fishing, with their utilization being currently scarce and only for own consumption of species such as the morey eel, conger eel and some crustaceans. An exception

*Received January 5, 2000. Accepted July 18, 2000. occurs in the use of traps for the capture of the caridean shrimp Plesionika edwardsi (Brandt, 1851), which is centred for the most part in the Spanish eastern coast, where boats dedicated exclusively to this species are used. The trap is a fixed bottom gear that consists of a cage with an easy entrance and difficult exit. It attracts the prey by means of baits placed inside. Their shape is variable and they are manufactured of cane, wicker and, currently, plastic. Different types of traps exist, with 
variable mesh size, depending on the target species. The traps for shrimp fishing used differ a little between zones (González et al., 1987, Lozano et $a l ., 1990$ a). For instance, in the port of Santa Pola, they are cylindrical, with $1 \mathrm{~cm}$ plastic mesh. They measure $45 \mathrm{~cm}$ in height by $50 \mathrm{~cm}$ in diameter and have a frame of steel ribs. They are lowered in lines of 350 traps and are collected every day. They are baited with horse mackerel, sable, common mackerel, etc. The fleet using this type of trap operates at 350-500 metres (200-250 fathoms) on the Alicante, Columbretes and Balearic coasts. In the port of Santa Pola, the type of ship that uses this gear has around 65 grt and an average length of $19 \mathrm{~m}$. The annual landings vary between 60 and 100 tonne/year (González et al., 1992).

The target species (Plesionika edwardsi Brandt, 1851 ) is a marine species with a wide distribution in low latitudes. It is found from the eastern Pacific (Philippines, Indonesia), to the eastern Atlantic (from South Carolina and north of the Bahamas to the Gulf of Mexico), the western Atlantic (from north-west Spain to Sierra Leona, including the archipelagos of the Azores, Madeira, Canaries and Cape Verde), the south-west Indian Ocean (around the Seychelles) and in the Mediterranean (Crosnier and Forest, 1973; Holthuis, 1980, 1987; Chace, 1985; Intès and Bach, 1989; González et al., 1990; Fransen 1991; Martins and Hargreaves, 1991; Biscoito, 1993; Carbonell and Abelló, 1998; Koukouras, et al., 1998). These authors have found the species at depths between 54 and $700 \mathrm{~m}$, mainly on muddy substrate, but also on sandy and rocky bottoms, both on the lower continental shelf and on the upper part of the slope. The maximum abundance is observed between depths of 150 and $300 \mathrm{~m}$ in the Canary Islands area (Lozano et al., 1990b; Caldentey et al, 1992; Santana et al., 1997), between 300 and $500 \mathrm{~m}$ in North Africa (Crosnier and Forest, 1973) and between 250 and $550 \mathrm{~m}$ on the Mediterranean coasts (Holthuis, 1987; Abelló et al, 1988; Company and Sardá, 1997; Carbonell and Abelló, 1998). It carries out seasonal vertical migrations. In winter it is concentrated in deep waters and ascends to shallower depths during the spring, reaching the shallowest depths during the summer, after which it begins to return to deeper water again in autumn. This behavioural pattern has been described for the species in the Canary Islands (Santana et al., 1997) and in the eastern Mediterranean (Thessalou-Legaki et al., 1989) as well as for another pandalid (P. narval) by González et al. (1997) in the Canary Islands.
In addition, a segregation of the sexes seems to exist based on the bathymetry, with a significantly larger proportion of females appearing at depths greater than 400 m (Company and Sardá, 1997).

The reproductive period is very extensive since it is possible to find ovigerous females at any time of the year, but especially between April and September in the Canary Islands (Santana et al., 1997), between January and March in the Azores (Martins and Hargreaves, 1991), from January to August off the Iberian peninsula (Zariquiey Alvarez, 1968). In the Western Mediterranean, it shows a shortened reproductive cycle with a progressive increase of females with active gonads during the winter and spring, which decreases during the summer and autumn (similar to the percentage of female egg-bearers) and a relationship exists between the size of the females and the size of the spawning (Company and Sardá, 1997). The existing size differences between sexes, with the females being larger that the males and the egg-bearers larger than the non egg-bearers, have been detected in the Seychelles (Intès and Bach, 1989), Azores (Martins and Hargreaves, 1991) and Canary Islands (Santana et al., 1997). The trophic diversity of Plesionika edwardsi is relatively low, since its diet is based fundamentally on Pasiphaea shivado, with scavenging having secondary importance in its feeding habits (Cartes, 1993).

However, despite the existence of these previous studies, it was considered opportune to carry out a series of experimental cruises based on trap-shrimp fishing, with the object of obtaining data of the distribution and yields of this species in the western Spanish Mediterranean. The studies carried out during the cruises were centred fundamentally on sampling the target species (Plesionika edwardsi) and the fauna associated with it. The study area comprised the whole Spanish Peninsular Mediterranean coast, extending from the limits of Punta Europa to Cape Creus, including the Alborán and Balearic islands.

\section{MATERIALS AND METHODS}

The material examined for this study came from the catches obtained using sets of traps in the course of experimental fishing cruises, carried out in the months of November 1998, March and June 1999. These cruises were undertaken on board the commercial vessel "Nuestra Madre Loreto" based in the port of Santa Pola (Alicante). A total of 50 fishing 
days were completed on board the boat, with 43 days of effective fishing, working in the Plesionika edwardsi fishery on their habitual bottom.

The area surveyed extended from Gibraltar to Cape Creus, including the Balearic Islands. This extensive area was divided into three geographical zones, according with the sampling scheme: Z1 Alborán Sea (Punta Europa-Cape Palos), Z2 Levant Coast (Cape Palos-Cape Creus) and Z3 Balearic Islands, with a cruise being carried out in each one of them in a different season: Balearic Islands in Autumn (November 98), Levant in Winter (March 99) and Alborán in Spring (June 99). In addition, for a better geographical analysis, a series of five subzones were considered: Alborán (Sz11), Gulf of Vera (Sz12), Gulf of Alicante (Sz21), south of the Ebro Delta (Sz22) and north of the Ebro Delta (Sz23).

Each fishing operation consisted on the deployment of four tackles called "tenas". Each tackle had an approximate length of 2.5 miles and was composed of 290 traps, which meant therefore that approximately 1160 traps were lowered in each operation. The depth varied between 250 and $350 \mathrm{~m}$. The characteristics of each haul were recorded (situation, depth, course, etc.), as well as those of the catch obtained (species, weights, etc.). In addition a record of the temperatures, at depths less than 400 $\mathrm{m}$, was made by means of the use of a "Minilog" probe. The gear was lowered at dusk and it was collected again the following day.

In the samplings carried out on board, two samples were taken from each "tena"; in one of them the individuals were measured by their cephalothoracic length (CL), from the posterior part of the left orbit to the centre of the posterior border of the carapace, to the nearest millimetre. The weight of the measured individuals altogether was recorded, as well as the total weight of the commercial category that belonged to each sample. An extrapolation was then carried out from the number of individuals in the sample, by size class and commercial category, to the total daily catch for the boat. A total of 43 sampling days was undertaken and a total of 29,000 individuals was examined. The second sample was preserved frozen until it could be processed in the laboratory. These specimens were measured by their cephalothoracic length (CL), to the nearest 0.1 millimetre, the individual weight was recorded accurately to the nearest 0.1 gram, as were the sex, the stage of sexual maturity and the presence of eggs in the females, and a total of 4,000 individuals were considered. The sex was determined by the presence or not of masculine appendages in the second pair of pleopods, by dissection under a stereoscopic microscope.

The relationships between the carapace length (CL) and the total weight were determined, adjusting the data to a potential relationship of the form: $\mathrm{W}=\mathrm{a} \cdot \mathrm{CL}^{\mathrm{b}}$, where $\mathrm{W}$ is the weight in grams, $\mathrm{CL}$ is the carapace length in milimetres, $a$ and $b$ are parameters that need to be estimated, and $b$ is the allometry coefficient. A significance test (Sokal and Rohlf, 1969) was also carried out in order to determine if the $b$ coefficient was different from 3. In addition, its significance level was determined with the Student t-test $(* * *<0.001 ; * *<0.01 ; *<0.05$ and not significant (ns) $>0.05$ ). These estimates were carried out separately for the relationships of the different groups; males, females without eggs and female egg-bearers, as well as for all the samples together. The differences in the slopes of the growth curves, obtained by least squares regression on the natural logarithmic transformation of the data, were contrasted statistically (ANCOVA) using the SYSTAT 5.04 programme.

Maturity was determined by macroscopic observation, adopting a scale of 5 maturity stages for females, based on colour intensity, with 1 being immature, 2 resting, 3 developing, 4 active, 5 prespawning (Company and Sardá, 1997). In addition, the developmental stages of the eggs were also determined in the female egg-bearers, according to the scheme of Company and Sardá (1997) differentiating three stages based on the coloration of the eggs: stage 1 (intense coloration), stage 2 (pale coloration) and stage 3 (total loss of coloration). The sex ratios were calculated for each sample, by size class, being expressed as the ratio of females to the total number of individuals (Sex Ratio $=\mathrm{N}^{\circ}+/$ $\left.\mathrm{N}^{\circ} \widehat{\delta}+\mathrm{N}^{\circ} q\right)$, and a test of significance $\mathrm{S}$ was carried out (Sokal and Rohlf, 1969) in order to assess the predominance of each sex in each size range.

For the study of the absolute growth (size-age relationship), the Von Bertalanffy growth factor model (VBGF) was chosen, which is defined as: $\mathrm{CL}_{\mathrm{t}}=\mathrm{CL}_{\infty}\left(1-\mathrm{e}^{-\mathrm{k}\left(\mathrm{t}-\mathrm{t}_{0}\right)}\right)$, with $\mathrm{CL}_{\infty}$ being the theoretical maximum length, $\mathrm{CL}_{t}$ the length at age $t, k$ the growth factor and $t_{0}$ the age at which the size is 0 . The growth Performance Index ( $\phi$ or $\phi^{\prime}$ ), according to consider the asymptotic weight or length, was also calculated for each sex. For the estimation of these parameters, the FISAT automatic calculation programme (Gayanilo, Sparre and Pauly, 1994) was used on the data grouped into $1 \mathrm{~mm}$ size classes, 
after smoothing 3 consecutive classes, taking the "best combination" from the parameters obtained (FISAT programme, ELEFAN subprogramme). The frequency histograms were then broken down into normal components by the Bhattacharya method (FISAT programme), on the length distribution histograms from the same files. These estimates were carried out separately for males and females.

A classification, by means of a hierarchical clustering, was undertaken to determinate the order of the main accompanying species based on the yields obtained, using the SYSTAT 5.0 programme. The geographical representations were carried out by means of the Geographical Information System "ARC VIEW 3.0".

\section{RESULTS}

\section{Sampling}

A total of 43 effective fishing days were carried out, that represented 172 trap lowering occasions from which samples were taken. Figure 1 shows the geographical location of the points sampled on the different cruises undertaken by "Nuestra Madre Loreto", and the importance of the yields obtained are proportionally represented. As can be seen, the distribution was very extensive, covering the whole of the Spanish Mediterranean coast, including the island of Alborán.

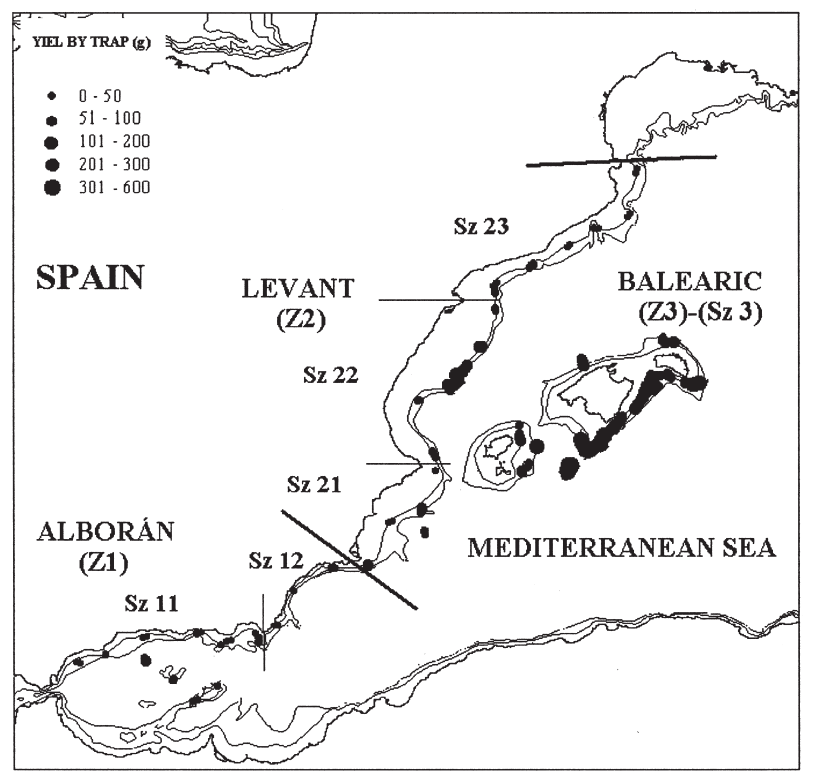

FIG. 1. - Distribution of the sampling points, zones (Z) and subzones $(\mathrm{Sz})$ established, with proportional representation of the Plesionika edwardsi yields obtained.
TABLE 1. - Statistics of the variables recorded during the trap lowerings sampled ( $\mathrm{n}=$ number of lowerings)

\begin{tabular}{|c|c|c|c|}
\hline & $\begin{array}{l}\text { Depth } \\
\text { (m) }\end{array}$ & $\begin{array}{l}\text { Temperature } \\
\left({ }^{\circ} \mathrm{C}\right)\end{array}$ & $\begin{array}{l}\text { Lowering time } \\
\text { (min) }\end{array}$ \\
\hline \multicolumn{4}{|l|}{ Total $(n=43)$} \\
\hline Minimum & 220.0 & 12.3 & 430.0 \\
\hline Maximum & 384.0 & 13.3 & 1223.0 \\
\hline Mean (sd) & $318.2( \pm 38.4)$ & $13.1( \pm 0.3)$ & $753.3( \pm 221.4)$ \\
\hline \multicolumn{4}{|c|}{ Z1 Alborán $(n=14)$} \\
\hline Minimum & 248.0 & 13.0 & 430.0 \\
\hline Maximum & 339.7 & 13.3 & 833.0 \\
\hline Mean (sd) & $307.9( \pm 24.7)$ & $13.2( \pm 0.1)$ & $592.9( \pm 119.2)$ \\
\hline \multicolumn{4}{|c|}{ Z2 Levant ( $\mathrm{n}=17)$} \\
\hline Minimum & 220.0 & 12.3 & 495.0 \\
\hline Maximum & 384.0 & 13.3 & 1223.0 \\
\hline Mean (sd) & $309.7( \pm 46.1)$ & $12.8( \pm 0.3)$ & $730.8( \pm 220.9)$ \\
\hline \multicolumn{4}{|c|}{ Z3 Balearic $(n=12)$} \\
\hline Minimum & 273.0 & 13.2 & 829.0 \\
\hline Maximum & 377.0 & 13.3 & 1118.0 \\
\hline Mean (sd) & $342.0( \pm 30.7)$ & $13.2( \pm 0.1)$ & $972.2( \pm 115.7$ \\
\hline
\end{tabular}

Generally, the depth of the samplings varied between 220 and $384 \mathrm{~m}$, with a mean depth of 318 $\mathrm{m}$. The temperature was very homogeneous (at around $13^{\circ} \mathrm{C}$ ), as would be expected at these depths. The greatest depth and mean lowering times, by zones, corresponded to the Balearic zone, while the lowest temperatures were observed in the Levant zone (Z2; Cape Palos to Cape Creus). For the subzones, the mean lowering depth was greater in Balearic (Sz3), south of the Ebro Delta (Sz22) and Alicante (Sz21), where the duration of the lowering times was also usually high. Table 1 shows the statistics of the variables recorded; depth, temperature and time of duration for all the samplings by zones or seasons.

\section{Yields}

The daily shrimp yields varied between a maximum total catch of $360 \mathrm{~kg}$ and a minimum of $100 \mathrm{~g}$, without counting the null catches. Figure 1 represents the yield (cpue) obtained for all the cruises carried out. The highest yields were achieved around the Balearic Islands, Columbretes Islands and occasionally at certain other points (off Cape Palos, Alicante and Alborán). Figure 2 shows the results of the yields, mean catch size and sex ratio found in the samplings. The yield of the target species (Plesionika edwardsi), or cpue, expressed in grams of shrimp by trap per day, reached a maximum value of 300 $\mathrm{g} /$ trap/day. The minimum value observed was 1.7 $\mathrm{g} /$ trap/day and the mean was $108.6 \mathrm{~g} /$ trap/day. If the 

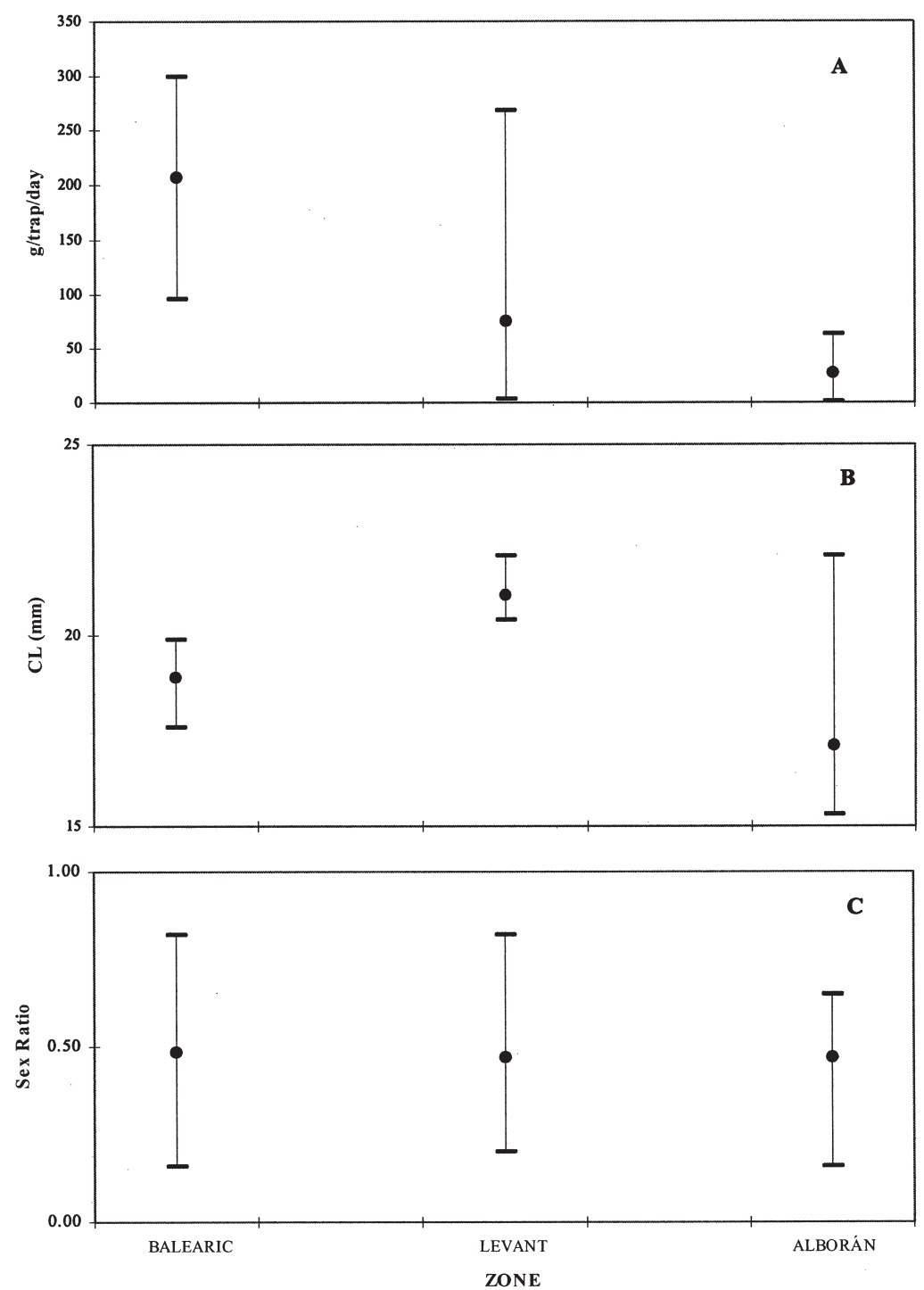

FIG. 2. - Representation of the maximum, minimum and mean yield values (A), maximum, minimum and mean sizes (B) and sex ratios (C) in the Plesionika edwardsi catches grouped by zones.

null fishings are included the mean cpue decreases to $88.4 \mathrm{~g} /$ trap/day. The largest yields by zones, as seen in Figure 1, show that Balearic being the most productive zone, since it had a mean cpue of 207.5 $\mathrm{g} /$ trap/day, followed by Levant with 75.7 cpue $\mathrm{g} /$ trap/day, whereas Alborán was the less profitable one (27.7 cpue g/trap/day). If the subzones are considered, Balearic still had a larger cpue, followed by subzone 22 (Cape San Antonio-Ebro Delta), Sz21 (Gulf of Alicante), Sz23 (Ebro Delta-Cape Creus), Sz11 (Alborán) and Sz12 (Gulf of Vera).

\section{Size composition}

The distribution of the mean individual size values for the catch group, showed (Fig. 2) that the largest mean sizes were in the Balearic zone, fol- lowed by the Levant and Alborán zones. The sizes of Plesionika edwardsi (Table 2) varied from a minimum size of $9.9 \mathrm{~mm}$ to a maximum of $29.1 \mathrm{~mm}$ cephalothoracic length (CL), with a mean of 19.1 $\mathrm{mm} \mathrm{CL} \mathrm{L}_{\infty}$ The males varied from a minimum of 10.1 $\mathrm{mm}$ to a maximum of $28.8 \mathrm{~mm} \mathrm{CL}$, with a mean of $19.6 \mathrm{~mm}$ CL. In the case of the females, the minimum size was $9.9 \mathrm{~mm}$ and the maximum $29.1 \mathrm{~mm}$ CL, while the mean was $20.8 \mathrm{~mm}$. In Figure 3, the length frequencies distribution are represented by size class for the total catches and the different zones.

\section{Relative growth}

The results obtained for the different size-weight relationships from the different groups (males, 

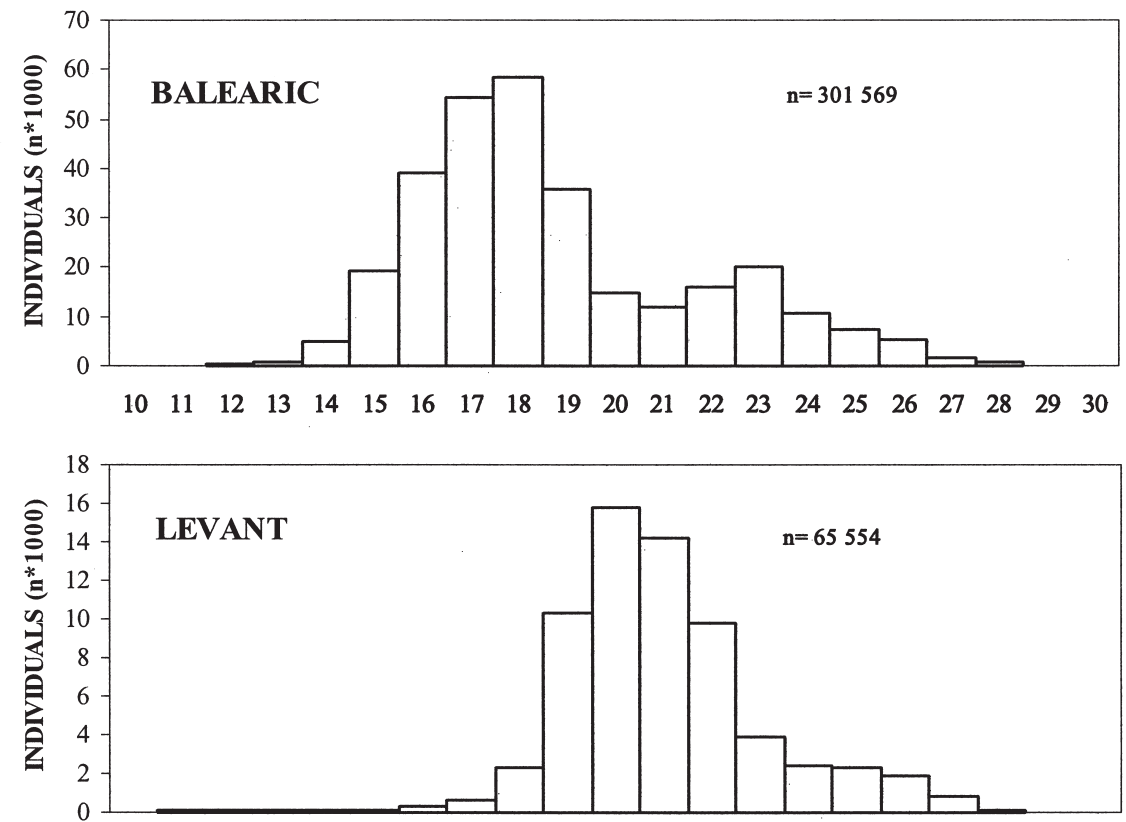

$\begin{array}{lllllllllllllllllllll}10 & 11 & 12 & 13 & 14 & 15 & 16 & 17 & 18 & 19 & 20 & 21 & 22 & 23 & 24 & 25 & 26 & 27 & 28 & 29 & 30\end{array}$

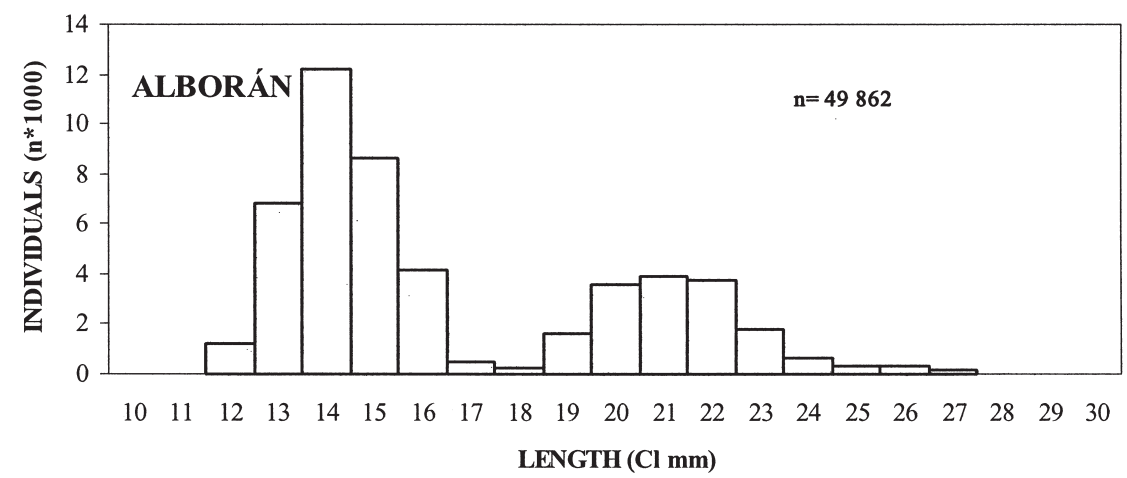

FIG. 3. - Size frequency histograms for the total catches obtained for the different zones.

TABLE 2. - Carapace length statistics for the Plesionika edwardsi specimens sampled (mm).

\begin{tabular}{|c|c|c|c|c|}
\hline Sizes & $\begin{array}{c}\text { Males } \\
(\mathrm{n}=2025)\end{array}$ & $\begin{array}{l}\text { Females } \\
(\mathrm{n}=2007)\end{array}$ & $\begin{array}{l}\text { Female non egg-bearers } \\
\qquad(\mathrm{n}=1167)\end{array}$ & $\begin{array}{c}\text { Female egg-bearers } \\
(\mathrm{n}=840)\end{array}$ \\
\hline $\begin{array}{l}\text { Minimum } \\
\text { Maximum } \\
\text { Mean (sd) } \\
\text { Median }\end{array}$ & $\begin{array}{c}10.1 \\
28.8 \\
19.6( \pm 3.5) \\
20.0\end{array}$ & $\begin{array}{c}9.9 \\
29.1 \\
20.9( \pm 4.2) \\
22.1\end{array}$ & $\begin{array}{c}9.9 \\
29.1 \\
19.1( \pm 4.3) \\
18.8\end{array}$ & $\begin{array}{c}13.6 \\
29.0 \\
23.5( \pm 2.1) \\
23.1\end{array}$ \\
\hline
\end{tabular}

TABLE 3. - Relative growth parameters (size-weight relationship: Weight $=\mathrm{a} \cdot$ Size $^{\mathrm{b}}$ ) found for Plesionika edwardsi; signif level: $* * *<0.001$, $* *<0.01, *<0.05$ and NS $>0.05$ in a "Student-t" test.

\begin{tabular}{lcccccc}
\hline Group & $\mathrm{a}$ & $\mathrm{b}$ & err.b & signif. & $\mathrm{r}^{2}$ & $\mathrm{n}$ \\
\hline Males & 0.001299 & 2.805 & 0.010 & $* *$ & 0.976 & 2025 \\
Females & 0.000907 & 2.943 & 0.010 & ns & 0.977 & 2007 \\
Female non egg-bearers & 0.001200 & 2.835 & 0.010 & $* *$ & 0.986 & 1167 \\
Female egg-bearers & 0.002834 & 2.597 & 0.032 & $*$ & 0.887 & 840 \\
\hline
\end{tabular}




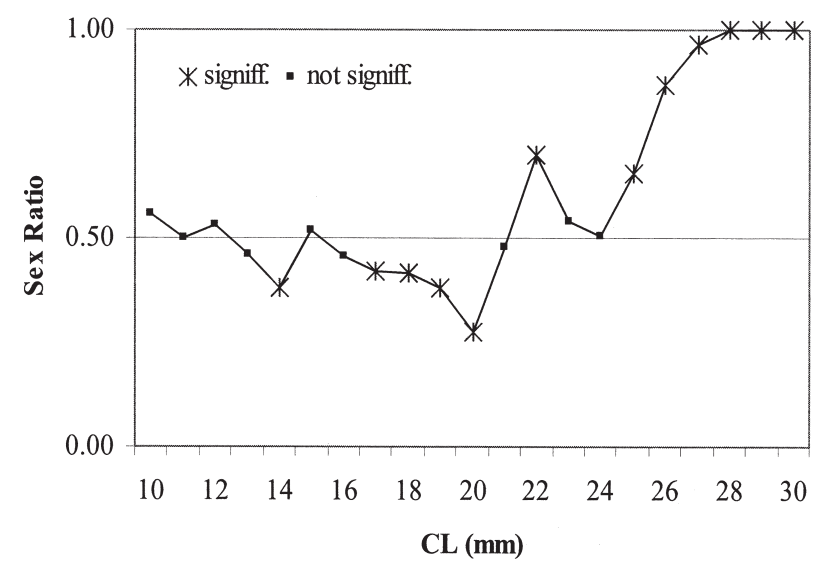

FIG. 4. - Representation of the sex ratios by size for Plesionika edwardsi, showing the significance of the dominance by sex in each size range (females dominance $>0.5$ ).

females, females without eggs and females eggbearers) are presented in Table 3. The values of allometry coefficient $\mathrm{b}$ were close to, but less than, 3 , although the value was not significantly different in the case of the females. In general the results are comparable to those obtained by Company and Sardá (1997) for the same species in the Mediterranean. The results of ANCOVA allowed the null hypothesis to be rejected $(\mathrm{F}=94.035 ; \mathrm{P}=0.000)$, since significant differences in the relative growth between males and females were detected.

\section{Reproduction}

The sex ratio by size class, for the total of sampled specimens, indicated (Fig. 4) that, after an initial stage up to $14-16 \mathrm{~mm}$ in which the proportion of sexes were similar, males usually prevailed significantly at sizes of $14-20 \mathrm{~mm}$ and the females dominated significantly in all the size ranges over $25 \mathrm{~mm}$. The sex ratio, for the whole study period, varied between a minimum of 0.16 to a maximum of 0.82 , while the mean was 0.49 (Fig. 2). In general, the sex ratio values varied little, both between zones (0.46$0.50)$ and for subzones (0.37-0.58), which indicated that a balance existed in the ratio between sexes, as also suggested by the mean values for the ratios.

Figure 5 shows a frequency distribution by sexes, after the application of the sex ratio to the total extrapolated catches. However, a slight dominance in the number of males was seen in the smallest sizes (up to $21 \mathrm{~mm}$ ), with the number of females increasing in the largest sizes, while at the same time two modes by each sex were highlighted, that could have corresponded to two age groups in each sex.

The percentages of females that were inactive (stages 1 and 2), active (stages 3,4 and 5) and spawning in the three seasons covered in the cruises, showed (Table 4) a progressive decrease of activity in winter and spring compared to the percentages found in autumn, although the percentages of female egg-bearers were higher in these seasons. The ratio

TABLE 4. - Percentages of gonadal stages (activity-inactivity) and of spawning presence in Plesionika edwardsi, by seasons and zones.

\begin{tabular}{llccc}
\hline Season & Zone & Inactivity (\%) & Activity (\%) & Spawning (\%) \\
& & & & \\
\hline \multirow{2}{*}{ Autumn } & Balearic & 1.05 & 93.15 & 5.80 \\
Winter & Levant & 10.64 & 51.82 & 37.54 \\
Spring & Alborán & 22.98 & 45.52 & 31.50 \\
\hline
\end{tabular}

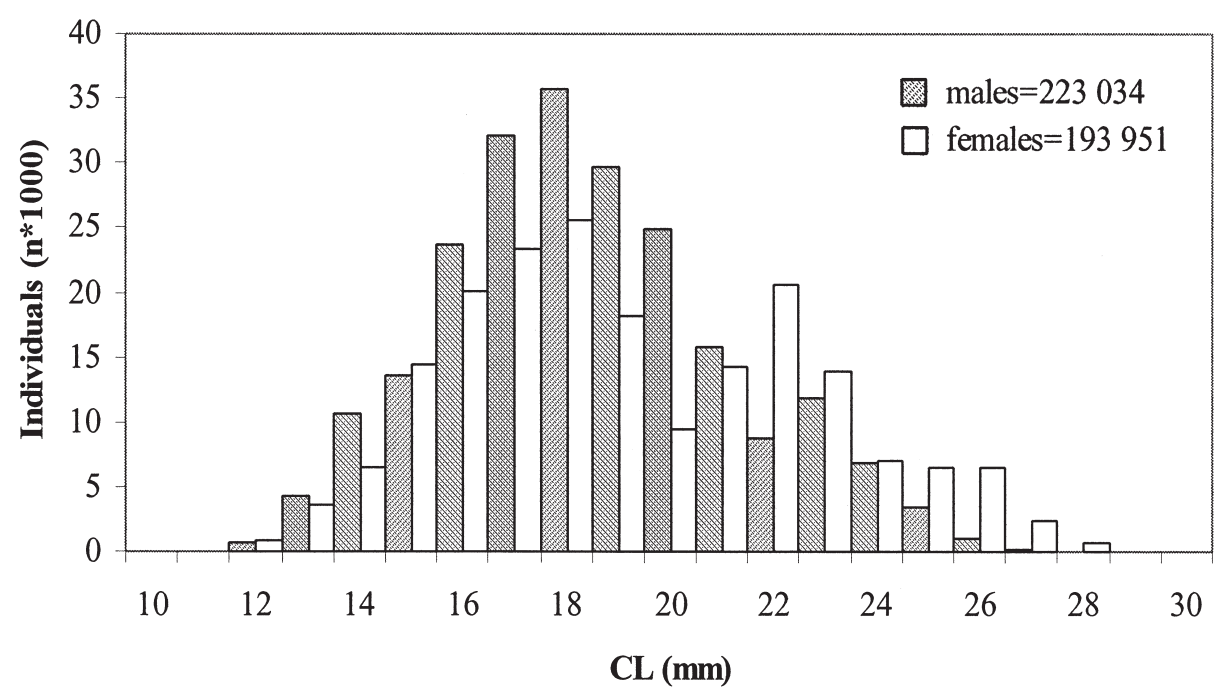

FIG. 5. - Histogram frequencies of males and females by size for Plesionika edwardsi, for all the total catches obtained, with reference to the total extrapolated individuals by sex. 
TABLE 5. - Results of the VBGF growth parameters (size-age relationship), obtained using the FISAT programme (ELEFAN), on length frequencies of male and female Plesionika edwardsi, with $\mathrm{t}_{0}$ adjusted for a $\mathrm{CL}_{1}$ of $14.8 \mathrm{~mm}$ in $\mathrm{m}$ and $15.3 \mathrm{~mm}$ in $\mathrm{f}$. $(\mathrm{CL}=$ theoretical maximum length, $\mathrm{CL}$ the length at age $\mathrm{t}, \mathrm{k}$ the growth factor and $\mathrm{t}_{0}$ age at which the size is $0 ; \phi^{\prime}=$ Growth Performance Index; $\mathrm{Rn}=$ Goodness index).

\begin{tabular}{lccccc}
\hline Sex & $\mathrm{L}_{\infty}(\mathrm{CL} \mathrm{mm})$ & $\mathrm{k}\left(\mathrm{year}^{-1}\right)$ & $\mathrm{t}_{0}$ & $\phi^{\prime}$ & $\mathrm{Rn}$ \\
\hline Males & 26 & 0.80 & -0.052 & 2.73 & 0.293 \\
Females & 31 & 0.80 & 0.146 & 2.89 & 0.289 \\
\hline
\end{tabular}

of mature spawners (eggs of stage 3 ) was at a minimum during the winter and the spring, whereas in the autumn it reached $20 \%$ of the total number of female egg-bearers.

\section{Absolute growth}

The different estimates of the Von Bertalanffy growth parameters, obtained by the application of the FISAT statistical package (ELEFAN subprogramme), are shown in Table 5, and they give some high values for the growth rate $(\mathrm{k})$. The analyses of modal progression gave different values for $\mathrm{CL}_{\infty}$ $(26.0$ and $31.0 \mathrm{~mm})$ and the same value of $\mathrm{k}(0.80$ year $\left.{ }^{-1}\right)$ for males and females. Differences observed in the growth parameters with other proposals for the same species in the Mediterranean (Company and Sardá, 1997) are located in males, mainly due to the different $\mathrm{CL}_{\infty}$ proposed.

Using the Bhattacharya method, three normal components were identified in the frequency distributions of each sex. In males, these were 14.80, 20.21 and $24.20 \mathrm{~mm} \mathrm{CL}$, in females they were 15.34, 22.00 and $26.39 \mathrm{~mm}$ CL for each identified component, respectively. When the values of the Growth Performance Index ( $\phi$ ') were considered, the females $\left(\phi^{\prime}=2.89\right)$ appeared to have faster growth rates than the males $\left(\phi^{\prime}=2.73\right)$, which would explain the accumulation of females in the largest sizes.

\section{Accompanying species}

A total of 15 crustacean and 12 fish species (4 Chondrichthyes and 8 Osteichthyes) were identified (Table 6).

The number of species (richness) that appeared in each trap lowering was considered as an indicator of diversity; and in this sense the number of species varied from a minimum of 2 to a maximum of 15 , with an average of 6.6 species per fishing. The rich-
TABLE 6. - List of accompanying species

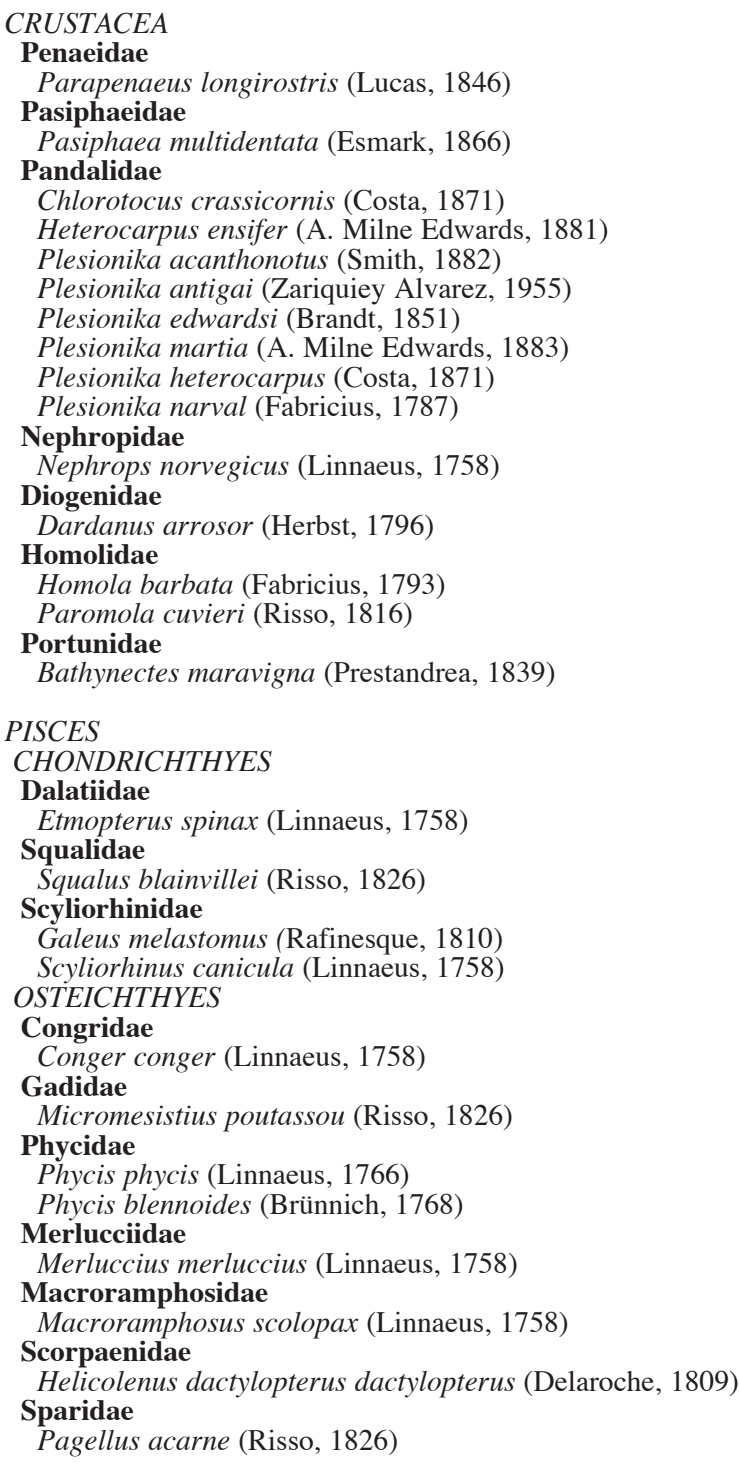

est zone in species was the Balearic in autumn with 8.9 species, followed by Levant in winter with 6.0, whereas Alborán was the less diverse with an average of 5.1 species per fishing in spring. If only subzones were considered, the Balearic (Sz3) and Cape San Antonio - Ebro Delta (Sz22) showed values of specific richness higher than the mean.

The order of the species based on their mean cpue is shown in Table 7, and the differences in yield between the main species and the different zones are indicated. The most important species, as far as mean cpue was concerned, were: Conger conger, Plesionika narval, Scyliorhinus canicula, Helicolenus dactylopterus and Galeus melastomus, although Scyliorhinus canicula did not appear in 
TABLE 7. - Hierarchical results for the main accompanying species found, based on their mean yields ( zones, as well as for all the fishings together (* absent).

\begin{tabular}{|c|c|c|c|c|c|c|c|}
\hline TOTAL & срие & Z1 (Alborán) & срие & Z2 (Levante-Cataluña) & срие & Z3 (Baleares) & срие \\
\hline Conger conger & 4.38 & Plesionika narval & 3.74 & Conger conger & 7.09 & Conger conger & 3.18 \\
\hline Plesionika narval & 1.66 & Conger conger & 2.09 & Plesionika narval & 0.94 & Scyliorhinus canicula & 1.73 \\
\hline Scyliorhinus canicula & 0.72 & Plesionika heterocarpus & 0.33 & Galeus melastomus & 0.71 & Helicolenus dactylopterus & s 1.72 \\
\hline Helicolenus dactylopterus & 0.62 & Helicolenus dactylopterus & $s 0.30$ & Scyliorhinus canicula & 0.61 & Phycis blennoides & 0.96 \\
\hline Galeus melastomus & 0.33 & Etmopterus spinax & 0.13 & Etmopterus spinax & 0.15 & Phycis phycis & 0.62 \\
\hline Phycis blennoides & 0.32 & Pasiphaea multidentata & 0.10 & Phycis blennoides & 0.14 & Pasiphaea multidentata & 0.36 \\
\hline Phycis phycis & 0.18 & Galeus melastomus & 0.06 & Helicolenus dactylopterus & 0.11 & Plesionika narval & 0.24 \\
\hline Plesionika heterocarpus & 0.15 & Chlorotocus crassicornis & 0.04 & Plesionika heterocarpus & 0.03 & Etmopterus spinax & 0.18 \\
\hline Etmopterus spinax & 0.15 & Parapenaeus longirostris & 0.02 & Chlorotocus crassicornis & 0.02 & Plesionika heterocarpus & 0.12 \\
\hline Pasiphaea multidentata & 0.14 & Phycis phycis & 0.01 & Plesionika martia & 0.02 & Galeus melastomиs & 0.09 \\
\hline Chlorotocus crassicornis & 0.05 & Plesionika martia & 0.002 & Pasiphaea multidentata & 0.01 & Chlorotocus crassicornis & 0.09 \\
\hline Parapenaeus longirostris & 0.01 & Phycis blennoides * & - & Phycis phycis & 0.01 & Parapenaeus longirostris & 0.02 \\
\hline Plesionika martia & 0.009 & Scyliorhinus canicula * & - & Parapenaeus longirostris & 0.003 & Plesionika martia & 0.007 \\
\hline
\end{tabular}

TABLE 8. - Hierarchical results for the main accompanying species found, based on their mean yields ( depth strata for all the fishings together (* absent).

\begin{tabular}{|c|c|c|c|c|c|c|c|}
\hline $200-250 m(n=2)$ & срие & $250-300 \mathrm{~m}(\mathrm{n}=7)$ & срие & $300-350 \mathrm{~m}(\mathrm{n}=25)$ & срие & $350-400 m(n=9)$ & срие \\
\hline Scyliorhinus canicula & 3.62 & onger $c$ & 3.58 & Conger & 3.65 & Conger conger & 7.49 \\
\hline Conger conger & 2.16 & Plesionika narval & 1.66 & Plesionika narval & 2.38 & Helicolenus dactylopterus & is 0.93 \\
\hline Helicolenus dactylopterus & 0.26 & Helicolenus dactylopterus & 0.54 & Scyliorhinus canicula & 0.92 & Galeus melastomus & 0.51 \\
\hline Plesionika narval & 0.02 & Phycis blennoides & 0.23 & Helicolenus dactylopterus & 0.56 & Phycis blennoides & 0.36 \\
\hline Plesionika heterocarpus & 0.02 & Phycis phycis & 0.17 & Galeus melastomus & 0.38 & Phycis phycis & 0.28 \\
\hline Parapenaeus longirostris & 0.01 & Pasiphaea multidentata & 0.17 & Phycis blennoides & 0.36 & Etmopterus spinax & 0.24 \\
\hline Phycis blennoides* & - & Scyliorhinus canicula & 0.11 & nika heterocarpus & 0.19 & Plesionika heterocarpus & 0.17 \\
\hline Phycis phycis* & - & Etmopterus spinax & 0.06 & multidentata & 0.18 & Chlorotocus crassicornis & 0.12 \\
\hline Etmopterus spinax* & - & Plesionika heterocarpus & 0.04 & hycis & 0.17 & Plesionika martia & 0.04 \\
\hline Pasiphaea multidentata* & - & Parapenaeus longirostris & 0.01 & Etmopterus spinax & 0.15 & Pasiphaea multidentata & 0.03 \\
\hline Chlorotocus crassicornis* & - & Chlorotocus crassicornis* & $=-$ & Chlorotocus crassicornis & 0.03 & Parapenaeus longirostris & 0.02 \\
\hline Galeus melastomus* & - & Galeus melastomus* & - & Parapenaeus longirostris & 0.02 & Plesionika narval & 0.003 \\
\hline Plesionika martia* & - & Plesionika martia* & - & Plesionika martia & 0.002 & Scyliorhinus canicula* & - \\
\hline
\end{tabular}

the Alborán zone. Nevertheless, the mean yields of these species were very low since they varied between a maximum of $7.1 \mathrm{~g} /$ trap/day (Conger conger) and a minimum of $0.002 \mathrm{~g} /$ trap/day (Plesionika martia).

If the species order was made by depth strata (Table 8), differences existed in the appearance of the species at the different depths, although it should be considered that the sampling by depth strata was not balanced. Nevertheless, Scyliorhinus canicula was the most important species in the $200-250 \mathrm{~m}$ stratum, but it was absent in the deepest stratum (350-400 m). Another species of great importance, Plesionika narval, increased its yield according with depth in the 200-350 m interval, shallower to deeper, until it reached a minimum in the deepest stratum, up to $350 \mathrm{~m}$. On the contrary, species such as Galeus melastomus, Plesionika martia and Chlorotocus crassicornis, went from being absent in the shallowest strata (200-300 m) to increasing their yields, as the depth increased.

\section{DISCUSSION}

The target species appeared in $81 \%$ of the fishings carried out. The highest yields were obtained around the Balearic Islands, Columbretes Islands and occasionally at certain other points (off Cape Palos, Alicante and in the Alborán zone). The Balearic was followed by Levant, whereas Alborán produced the minimum yields. A tendency appears to exist for fishing with greater intensity at greater depth and for longer periods of time in the most productive zones. The mean values and maxima found are very similar to those yields reported by Aquila (1991) in the Alicante gulf, being lower than those from Secci et al, 1994 in Sardinia.

The largest mean length was found in the Levant zone, between Cape Palos and Cape Creus, and increased in a gradient towards the north, since in the subzones corresponding to Cape San Antonio - Ebro Delta and from this point to Cape Creus the largest mean lengths were found. On the contrary, the smallest mean sizes were found towards the south, more 
specifically in the Alborán zone. In general, the catch mean length showed narrower ranges (mainly in maximum values) and close means, which are the same in the case of the males and smaller for the females than those found in the Atlantic (Santana et al., 1997), although they are similar to those found by other authors in the Mediterranean (Carbonell and Abelló, 1998). The ranges and mean for the males were very similar to those of the females

The size-weight relationship suggests the existence of a negative allometry in the growth of the Plesionika edwardsi males in the Mediterranean during their development, with the small specimens growing more vigorously than the large ones and in general, the females more than the males. The comparison between the growth curve slopes of Plesionika edwardsi, as well as the results obtained in the analyses of the variance, show that significant differences exist in the relative growth between males and females, as has already been described in other pandalids (Sanz, 1986).

The estimation undertaken for the absolute growth parameters gives smaller values of $\mathrm{L}_{\infty}$ than the maxima length values reported in the Atlantic by other authors (Santana et al., 1997), meanwhile its calculated $\mathrm{L}_{\infty}$ are smaller than ours, which could suggest that the species grows less in the Mediterranean, despite showing some high growth rates $(\mathrm{k})$. The modes related with age classes are different to those proposed by Santana et al. (1997), since, in our case, both the males and the females would reach $15 \mathrm{~mm}$ $\mathrm{CL}$ in the first year, with their growth patterns differing from this point onwards. Females have faster growth rates than males when considering the Growth Performance Index ( $\phi$ '). In fact Santana et al. (1997) found similar $\phi$ ' values for the species at Canarian waters. The growth Performance Index ( $\phi$ or $\phi$ ') has been shown to be remarkably constant between different populations of the same species. In a study over 18 Mediterranean deep-water decapod crustacean species (Company and Sardá, 2000) all the $\phi$ values found shown similar values, being significantly different to those of other crustacean families. In the present work $\phi$ values for males (0.63) and for females (0.81) are closer, but not equal, to those proposed by Company (2000). Small differences may by ascribed to differences in the number of individuals in the sample as well as to slight differences in sizes sampled.

In general, the mean sex ratio values varied little, both between zones and subzones, therefore we can consider that a balance exists in the ratio between sexes, as the means of the ratio values indicate
(0.49). According to Carbonell and Abelló (1998), the sex ratios favour the females slightly $(0.58)$, perhaps because their bathymetric sampling range was wider, and they were therefore able to catch a larger number of females in the samplings down to greater depth (Company and Sardá, 1997). However, a slight dominance of the number of males is observed in the smallest sizes and a slight dominance of the females in the largest. Numerical differences between sexes, in certain size classes, could be due to differences in the growth or in their differential mortality. In fact, females seem to have quicker growth rates than the males, which would explain the accumulation of females in the largest sizes.

The seasonal progressive increase in the gonadal activity of females is contradicted by a concomittant decrease in the ratios of female egg-bearers. However, in other studies (Company and Sardá, 1997) the percentages of females with active gonads also appear very variable. For this reason it could be more indicative to use the percentage of female egg-bearers, which happened to be smaller during the autumn, therefore reinforcing the idea that the spawning season occurs during the winter and spring, but decreases during the summer and autumn (Company and Sardá, 1997). The existence of a larger proportion of mature spawners in the autumn, despite being the season with a smaller percentage of spawnings, could be attributed to slower maturation, therefore leading to longer egg development before hatching, and longer attachment to the females.

A total of 15 crustacean and 12 fish species were identified as accompanying species. The most abundant, as regards their mean cpue, were Conger conger, Plesionika narval and Scyliorhinus canicula. In addition, the appearance of Heterocarpus ensifer, of which 5 specimens were caught in different trap lowerings during the three cruises, deserves a special mention, since, despite being a common species in the Atlantic, it is a very rare species in the Western Mediterranean. Only one example has been recorded previously in Balearic waters (Massutí and Oliver, 1975), although we do not know of its deposit in any collection. In our case, a representative specimen of those caught has been deposited in the Biological Reference Collections of the ICMCSIC in Barcelona (Code: ICMD 100/2000).

The richest zone in species is Balearic, followed by Levant and Alborán being the less "diverse". If we only consider subzones the Balearic and Cape San Antonio-Ebro Delta show values of specific richness higher than the mean. Differences exist in 
the appearance of the species at the different depths. Scyliorhinus canicula and Plesionika narval, species of great importance in the first three strata (200-350 m), decrease their yields drastically in the deepest stratum (up to $350 \mathrm{~m}$ ). On the contrary, species such as Galeus melastomus, Plesionika martia and Chlorotocus crassicornis, go from being absent in the two shallowest strata $(200-300 \mathrm{~m})$ to increasing their yields, as the depth increases, which coincides with that described for Plesionika martia and Chlorotocus crassicornis in the Western Mediterranean by Carbonell and Abelló (1998). In the case of Plesionika narval, these authors point out its disappearance from $400 \mathrm{~m}$, which agrees with the drastic reduction of their yields that we detected in the deepest stratum. Nevertheless, the mean yields of these species are very low, due to the high selectivity of the fishing gear used.

\section{ACKNOWLEDGEMENTS}

We wish to thank D. José Durá López, the owner of the "Nuestra Madre Loreto" and its captain and crew for their collaboration in the development of the studies, as well as Dr. Pere Abelló for critically reading the manuscript. This project was financed by the Secretaría General de Pesca Marítima from the Ministerio de Agricultura y Pesca as a pilot experimental fishing study.

\section{REFERENCES}

Abelló, P., F.J. Valladares and A. Castellón. - 1988. Analysis of the structure of decapod crustacean assemblages off the Catalan coast (North-Western Mediterranean). Mar. Biol., 98: 39-49.

Aquila, A. - 1991. Crevette profonde: Peche test en Mediterranee. Oceanorama 17.

Biscoito, M.J. - 1993. An account of the shrimps of the family Pandalidae (Crustacea, Decapoda, Caridea) in Madeiran waters. Cour. Forsch.-inst. Senkenberg, 159: 321-325.

Caldentey, M.A., J.I. Santana, J.A. Gonzalez and I.J. Lozano. 1992. Observaciones biológico-pesqueras sobre los pandálidos (Crustacea, Decapoda, Caridea) de Canarias. Actas V Simp. Iber. estud. Bentos Mar. Vol 2.

Carbonell, A. and P. Abelló. - 1998. Distribution characteristics of pandalid shrimps (Decapoda: Caridea: Pandalidae) along the Western Mediterranean Sea. J. Nat. Hist., 32: 1463-1474.

Cartes, J.E. - 1993. Diets of deep-water pandalid shrimps on the Western Mediterranean slope. Mar. Ecol. Prog. Ser., 96: 49-61.

Chace, F.A. - 1985. The caridean shrimps (Crustacea: Decapoda) of the Albatross Philippine Expedition, 1907.1910. Smiths. Contr. Zool. 411: 1-143.

Company, J.B. and F. Sardá. - 1997. Reproductive patterns and population characteristics in five deep-water pandalid shrimps in the Western Mediterranean along a depth gradient (150-1100 m). Mar. Ecol. Prog. Ser., 148: 49-58.

Company, J.B. and F. Sardá. - 2000. Growth parameters of deepwater decapod crustaceans in the Northwestern Mediterranean Sea: a comparative approach. Mar. Biol., 136: 79-90.

Crosnier, A. and J. Forest. - 1973. Les crevettes profondes de l'At- lantique oriental Tropical. Faune Trop. (OSTROM) 19.

Fransen, C.H.J.M. - 1991. Preliminary report on Crustacea collected in the eastern part of the North Atlantic during the CANCAP and MAURITANIA Expeditions. Nat. Natuurhist. Mus. VI:200pp.

Gayanilo jr, F.C., P. Sparre and D. Pauly. - 1994. The FAOICLARM Stock assessment Tools (FISAT) User's Guide. FAO Computerized Information Series (Fisheries) $n^{\circ} 6$. Rome, FAO, $186 \mathrm{pp}$.

González, J., J. Carrillo and J. Santana. - 1987. Primeras experiencias en Canarias con nasas camaroneras levantinas. Canarias Agraria y Pesquera, 3: 19-20.

González, J.A, I.J. Lozano, M.A. Caldentey, J.I. Santana, J.A. Gómez and R. Castillo. - 1988. Resultados de la campaña de Prospección pesquera "CANARIAS 85". Infor. Téc. Inst. Españ. Oceanogr. 57.

González, J.A, M.A. Caldentey and J.I. Santana. - 1990. Catálogo de las especies de la familia Pandalidae (Crustacea, Decapoda, Caridea) en Canarias. Vieraea, 19: 141-151.

González, J.A, J. Carrillo, J. Santana, P. Martinez and F. Vizuete. 1992. La pesquería de quisquilla, Plesionika edwardsi (Brandt, 1851), con tren de nasas en el Levante español. Ensayos a pequeña escala en Canarias. Inf. Técn. Sci. Mar., 170.

González, J.A, V.M. Tuset, I.J. Lozano and J.I. Santana - 1997. Biology of Plesionika narval (Crustacea, Decapoda, Pandalidae) around the Canary Islands (Eastern Central Atlantic). Estuar. Coast. Shelf Sci., 44: 339-350.

Holthuis, L.B. - 1980. F.A.O. species catalogue. 1. Shrimps and prawns of the world. An annotated catalogue of species of interest to fisheries. F.A.O. Fish. Synop. 125(1): 271pp.

Holthuis, L.B. - 1987. Crevettes. In: Fiches FAO d'identification des Epeces pour les besoins de la Peche. Mediterranee et Mer noire. Zone de Peche 37. Fishcher,W., Bauchot, M.L. and Schneider, M. (Eds) Rome 1: 189-192.

Intès, A. and P. Bach. - 1989. La campagne "CEPROS" du N.O.ALIS sur les accores de plateau Seychellois. Mahe.Convention France-Seychelles 87/206/01.

Koukouras, A., A. Kallianotis and D. Vafidis, - 1998. The decapod Genera Plesionika Bate (Natantia) and Munida Leach (Anomura) in the Aegean sea. Crustaceana, 71(6): 714-720.

Lozano, G., J. Carrillo, M.A. Caldentey, J. Santana, J. Lozano, J. Gonzalez, et al. - 1990b. Distribución estacional y batimétrica de pandálidos en el talud de Gran Canaria. Actas VI Simp. Ibér. Estud. Bentos Mar., De. Bilbilis, Palma de Mallorca.

Lozano, G., J. Santana, J. Gonzalez, J. Lozano, et al. - 1990a. Metodología y resultados de campañas de pesca experimental con nasas en las Islas Canarias (Proyecto 17/30.04.86). Actas VI Simp. Ibér. Estud. Bentos Mar., De. Bilbilis, pp. 335-344, Palma de Mallorca.

Martins, H.R. and P.M. Hargreaves. - 1991. Shrimps of the family Pandalidae and Hippolytidae (Crustacea: Decapoda) caught in benthic traps off the Azores. Arquipélago, 9: 47-61.

Massutí, M. and P. Oliver. - 1975. Iniciación al estudio de nuevos fondos de arrastre en el talud continental de las islas Baleares. Public. Téc. Dir. Gral. Pesca. Madrid

Santana, J.I., J.A. González, I.J., Lozano and V.M. Tuset. - 1997. Life history of Plesionika edwardsi (Crustacea, Decapoda, Pandalidae) around the Canary Islands, Eastern Central Atlantic. $S$. Afr: J. Mar. Sci. 18: 39-48.

Sanz, A. - 1986. Observaciones sobre la biología de Plesionika heterocarpus (Costa, 1871) (Crustacea: Decapoda: Pandalidae) en el Mediterráneo Oeste. Actas VII Jorn. Asoc. Esp. Entomología. Sevilla, pp: 175-179.

Secci, E., S. Campisi, R. Comunian, M.C. Follesa, A. Sabatini, M. Stefani and A. Cau. - 1994. Primi risultati sull'utilizzo sperimentale delle nasse ai livelli epi-mesobatiali. Biol. Mar. Medit., 1(1): 343-344.

Sokal, R.R. and F.J. Rohlf. - 1969. Biometry: The principles and practice of statistics in biological research. W.H. Freeman and Co., San Francisco, U.S.A.

Thessalou-Legaki, M., A. Frantzis, K. Nassiokas and S. Hatzinikolau. - 1989. Depth zonation in a Parapandalus narval (Crustacea, Decapoda, Pandalidae) population from Rhodos Island, Greece. Estuar. Coast. Shelf Sci., 29: 273-284.

Zariquiey, R. - 1968. Crustáceos decápodos Ibéricos. Investigación Pesq., Barcelona 32: xv + 510 pp.

Scient. ed.: P. Abelló 